\title{
Barriers to Antiretroviral Therapy Adherence Among HIV-Positive Hispanic and Latino Men Who Have Sex with Men — United States, 2015-2019
}

\author{
Stacy M. Crim, $\mathrm{MPH}^{1}$; Yunfeng Tie, $\mathrm{PhD}^{1}$; Linda Beer, $\mathrm{PhD}^{1}$; John Weiser, $\mathrm{MD}^{1}$; Sharoda Dasgupta, $\mathrm{PhD}^{1}$
}

During 2018, estimated incidence of human immunodeficiency virus (HIV) infection among Hispanic and Latino (Hispanic/Latino) persons in the United States was four times that of non-Hispanic White persons (1). Hispanic/Latino men who have sex with men (MSM) accounted for $24 \%(138,023)$ of U.S. MSM living with diagnosed HIV infection at the end of 2018 (1). Antiretroviral therapy (ART) adherence is crucial for viral suppression, which improves health outcomes and prevents HIV transmission (2). Barriers to ART adherence among Hispanic/Latino MSM have been explored in limited contexts (3); however, nationally representative analyses are lacking. The Medical Monitoring Project reports nationally representative estimates of behavioral and clinical experiences of U.S. adults with diagnosed HIV infection. This analysis used Medical Monitoring Project data collected during 2015-2019 to examine ART adherence and reasons for missing ART doses among HIV-positive Hispanic/Latino MSM $(1,673)$. On a three-item ART adherence scale with 100 being perfect adherence, $77.3 \%$ had a score of $\geq 85$. Younger age, poverty, recent drug use, depression, and unmet needs for ancillary services were predictors of lower ART adherence. The most common reason for missing an ART dose was forgetting; $63.9 \%$ of persons who missed $\geq 1$ dose reported more than one reason. Interventions that support ART adherence and access to ancillary services among Hispanic/Latino MSM might help improve clinical outcomes and reduce transmission.

The Medical Monitoring Project used a two-stage sampling method. During the first stage, 16 states and one territory were sampled from all U.S. states, the District of Columbia, and Puerto Rico. During the second stage, simple random samples of adults with diagnosed HIV infection were selected for each participating jurisdiction from the National HIV Surveillance System, a census of persons with diagnosed HIV infection in the United States. In-person or telephone interviews were conducted during the 2015-2018 data cycles, ${ }^{*}$ in which selfreported sociodemographic characteristics, ART adherence, drug and alcohol use, and symptoms of depression ${ }^{\dagger}$ and anxiety ${ }^{\S}$ were ascertained.

\footnotetext{
* Interviews are conducted during June-May for each annual cycle; this analysis combined 2015-2018 cycles. Response rates for participants ranged from 40\% to $46 \%$ by cycle year.

$\dagger$ Symptoms of depression during the previous 2 weeks were assessed using the eight-item Patient Health Questionnaire.

$\$$ Symptoms of anxiety during the previous 2 weeks were assessed using the Generalized Anxiety Disorder Scale.
}

\section{INSIDE}

1443 Characteristics Associated with Adults Remembering to Wash Hands in Multiple Situations Before and During the COVID-19 Pandemic — United States, October 2019 and June 2020

1450 Case Series of Multisystem Inflammatory Syndrome in Adults Associated with SARS-CoV-2 Infection - United Kingdom and United States, March-August 2020

1457 Adolescent with COVID-19 as the Source of an Outbreak at a 3-Week Family Gathering - Four States, June-July 2020

1460 Trends in COVID-19 Incidence After Implementation of Mitigation Measures Arizona, January 22-August 7, 2020

1464 Progress Toward Poliomyelitis Eradication Afghanistan, January 2019-July 2020

1470 QuickStats

Continuing Education examination available at https://www.cdc.gov/mmwr/mmwr_continuingEducation.html

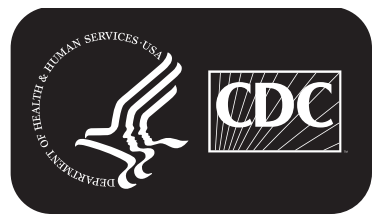

U.S. Department of Health and Human Services Centers for Disease Control and Prevention 
ART adherence during the 30 days before the interview was assessed using a three-item scale; responses were aggregated and transformed into a previously validated composite score (range $=0-100)$, which has high internal reliability and is consistent with electronic drug monitoring measures $(4,5)$. Ancillary services were defined as services that enable and support participants' retention in HIV care (6). Sustained viral suppression was defined as all viral load measurements in the previous 12 months documented as undetectable or $<200$ viral RNA copies/mL.** Reasons for most recent missed ART dose consisted of predefined options that respondents could select and were limited to the 2018 data cycle because of skip-pattern changes that limited comparability with earlier data cycles.

This analysis was limited to men who self-identified as Hispanic/Latino, regardless of race, who were currently taking ART and self-identified as MSM (i.e., gay or bisexual or who reported having had sex with one or more men during the previous 12 months) $(1,673)$. Among HIV-positive Hispanic/ Latino MSM, the three components of the ART adherence scale and the ART adherence scale score (dichotomized as $\geq 85$ versus $<85$ on the basis of the distribution of scores), by

\footnotetext{
I Ancillary services include HIV case management services, ART adherence counseling services, AIDS Drug Assistance Program services, patient navigation services, HIV peer-group support, dental services, drug or alcohol counseling or treatment, mental health services, transportation assistance, shelter/housing services, Supplemental Security Income, Social Security Disability Insurance, food assistance, meals or food services, interpreter services, or legal services.

** Persons with unknown viral load measurements were analyzed with those with detectable viral loads.
}

selected characteristics, were examined by using weighted percentages with corresponding 95\% confidence intervals (CIs). Characteristics associated with high ART adherence (score $\geq 85$ ) were assessed by using a multivariable logistic regression model to describe adjusted prevalence ratios (aPRs) with predicted marginal means $(7)$. Characteristics with bivariate associations with ART adherence $(\mathrm{p}<0.1)$ were eligible for possible inclusion in the model. Backward selection was used to determine final model selection, where eligible covariates with significant associations $(\mathrm{p}<0.05)$ were retained in the final model. Among persons who reported ever missing $\geq 1$ ART dose (348 during the 2018 data cycle), reasons for most recent missed dose were described; participants could report more than one reason. Sustained viral suppression status was assessed, comparing those with higher adherence (i.e., adherence score $\geq 85$ ) with those with lower adherence (i.e., adherence score $<85$ ), using a univariate prevalence ratio (PR). All analyses were weighted to adjust for individual nonresponse and poststratified to known population totals by age, race/ethnicity, and sex from the National HIV Surveillance System. Analyses were conducted using survey procedures in SAS software (version 9.4; SAS Institute) and SAS-callable SUDAAN (version 11.0.3; RTI International).

During 2015-2019, 57.4\% of Hispanic/Latino MSM reported taking all ART doses during the previous month, $52.9 \%$ reported doing an excellent job taking their medications, and $69.2 \%$ reported always taking their medications as recommended (Table 1). ART adherence was high for $77.3 \%$

The MMWR series of publications is published by the Center for Surveillance, Epidemiology, and Laboratory Services, Centers for Disease Control and Prevention (CDC), U.S. Department of Health and Human Services, Atlanta, GA 30329-4027.

Suggested citation: [Author names; first three, then et al., if more than six.] [Report title]. MMWR Morb Mortal Wkly Rep 2020;69:[inclusive page numbers].

\section{Centers for Disease Control and Prevention Robert R. Redfield, MD, Director Anne Schuchat, MD, Principal Deputy Director} Chesley L. Richards, MD, MPH, Deputy Director for Public Health Science and Surveillance Rebecca Bunnell, PhD, MEd, Director, Office of Science Arlene Greenspan, PhD, Acting Director, Office of Science Quality, Office of Science Michael F. Iademarco, MD, MPH, Director, Center for Surveillance, Epidemiology, and Laboratory Services

\section{MMWR Editorial and Production Staff (Weekly)}

Charlotte K. Kent, PhD, MPH, Editor in Chief Jacqueline Gindler, MD, Editor

Paul Z. Siegel, MD, MPH, Guest Associate Editor Mary Dott, MD, MPH, Online Editor Terisa F. Rutledge, Managing Editor

Douglas W. Weatherwax, Lead Technical Writer-Editor

Glenn Damon, Soumya Dunworth, PhD,

Teresa M. Hood, MS, Narue J. Wright-Jegede, PhD, Technical Writer-Editors

Michelle E. Bonds, MBA

Matthew L. Boulton, MD, MPH

Carolyn Brooks, $\mathrm{ScD}$, MA

Jay C. Butler, MD

Virginia A. Caine, MD
Martha F. Boyd, Lead Visual Information Specialist Alexander J. Gottardy, Maureen A. Leahy,

Julia C. Martinroe, Stephen R. Spriggs, Tong Yang, Visual Information Specialists

Quang M. Doan, MBA, Phyllis H. King,

Terraye M. Starr, Moua Yang,

Information Technology Specialists

MMWR Editorial Board

Timothy F. Jones, MD, Chairman

Katherine Lyon Daniel, PhD

Jonathan E. Fielding, MD, MPH, MBA

David W. Fleming, MD

William E. Halperin, MD, DrPH, MPH

Jewel Mullen, MD, MPH, MPA Jeff Niederdeppe, $\mathrm{PhD}$
Patricia Quinlisk, MD, MPH

Patrick L. Remington, MD, MPH Carlos Roig, MS, MA William Schaffner, MD

Morgan Bobb Swanson, BS 


\section{Summary}

What is already known about this topic?

Antiretroviral therapy (ART) adherence is crucial for viral suppression, a critical outcome for maintaining health in persons with HIV infection. Hispanic/Latino men who have sex with men (MSM) have disproportionately high HIV infection rates; their barriers to ART adherence have not been extensively explored.

What is added by this report?

ART adherence was lower among younger Hispanic/Latino MSM and those who experienced poverty or reported drug use, depression, or unmet ancillary service needs. The most common reason for missing ART doses was forgetting (63.1\%); $63.9 \%$ who missed doses reported multiple reasons.

What are the implications for public health practice?

Expanding access to ancillary services among Hispanic/Latino MSM, particularly those experiencing barriers to ART adherence, might improve clinical outcomes.

(Table 2). Younger persons and those at or below the federal poverty threshold were less likely to report high ART adherence. Reported ART adherence was lower among persons who reported drug use in the previous year $(67.2 \%)$ than among those who did not $(81.9 \%)$, among persons who reported a recent history of depression $(66.3 \%)$ than among those who did not $(79.9 \%)$, and among persons who had unmet needs for ancillary services $(71.6 \%)$ than among those without unmet needs $(83.0 \%)$. Anxiety and history of homelessness were not associated with ART adherence after adjustment for other factors. Among persons who had ever missed $\geq 1$ ART dose, the most commonly reported reasons for the most recent missed dose were forgetting to take medication (63.1\%), a change in daily routine or travel (42.3\%), and having fallen asleep early or overslept (33.6\%) (Table 3). Approximately $64 \%$ of persons who missed $\geq 1$ dose reported multiple reasons for missing ART. Sustained viral suppression was more common among persons with ART adherence scores $\geq 85(75.3 \%)$ than among persons with lower scores $(59.7 \%$; $\mathrm{PR}=0.61 ; 95 \% \mathrm{CI}=0.51-0.74)$.

\section{Discussion}

Although high overall, self-reported ART adherence among HIV-positive Hispanic/Latino MSM was lower among younger persons, those living at or below poverty, and those who reported drug use, depression, and unmet needs for ancillary services. The most commonly reported reason for last missed ART dose was forgetting to take it; three in five persons reported multiple reasons. These results indicate possible avenues for interventions to help Hispanic/Latino MSM engage in care and remain ART-adherent.
TABLE 1. Adherence to antiretroviral therapy (ART) among Hispanic/ Latino men who have sex with men currently taking ART $(N=1,673)-$ Medical Monitoring Project, United States, 2015-2019

\begin{tabular}{lcr}
\hline Interview question & No. $^{*}$ & $\%(95 \% \mathrm{Cl})^{\dagger}$ \\
\hline How many days did you miss $\geq 1$ dose of any of your HIV medicines? $\$$ \\
0 & 943 & $57.4(54.7-60.1)$ \\
$1-2$ & 489 & $29.2(26.7-31.7)$ \\
$3-5$ & 151 & $8.5(6.9-10.1)$ \\
$6-10$ & 52 & $3.0(1.9-4.0)$ \\
$\geq 11$ & 36 & $2.0(1.3-2.6)$
\end{tabular}

How well did you do at taking your HIV medicines in the way you were supposed to? $\$$

Very poor $\quad 18 \quad 0.9(0.5-1.3)$

Poor $21 \quad 1.3(0.6-2.0)$

Fair $\quad 86 \quad 5.5(4.0-7.0)$

Good $207 \quad 11.6(9.9-13.3)$

Very good $\quad 472 \quad 27.8(25.1-30.5)$

Excellent $\quad 869 \quad 52.9$ (49.9-55.9)

How often did you take your HIV medicines in the way you were supposed to? $\$$

\begin{tabular}{lcr} 
Never & 14 & $0.7(0.3-1.1)$ \\
Rarely & $-\pi$ & -9 \\
Sometimes & 36 & $2.0(1.4-2.7)$ \\
Usually & 79 & $5.0(3.7-6.4)$ \\
Almost always & 374 & $22.7(20.1-25.3)$ \\
Always & 1,163 & $69.2(66.4-72.0)$ \\
\hline
\end{tabular}

Abbreviations: $\mathrm{Cl}=$ confidence interval; $\mathrm{HIV}=$ human immunodeficiency virus. * Numbers might not sum to total because of missing data, and percentages might not sum to 100 because of rounding.

† Percentages and corresponding $\mathrm{Cls}$ are weighted percentages.

$\S$ Time frame for all questions is the 30 days before the interview.

I Value is excluded because coefficient of variation $>0.30$.

Ancillary services (e.g., counseling for mental health and substance use disorders, financial support, and assistance with food and housing) might reduce barriers to ART adherence. Colocating these services with outpatient care (e.g., HIV patient-centered medical home model of the Ryan White HIV/AIDS Program)(8) can encourage engagement and retention in HIV care. In a study of ART adherence among African American and Hispanic/Latino MSM, younger participants reported better adherence when their care location also offered ancillary services to help them address other needs (3). Making these services more broadly available and easily accessible might remove barriers to ART adherence and improve health outcomes.

Approximately two thirds of persons who had missed $\geq 1$ ART dose reported having forgotten to take it. Interventions that include reminders might help prevent these lapses. An analysis of systematic reviews of ART adherence interventions found that text messaging interventions were among the most successful for improving both self-reported adherence and viral load (9). Other interventions that have increased ART adherence include peer support and cognitive behavioral therapy. Interventions that include multiple strategies were more likely to increase ART adherence, although effects were often short-lived (10). 
TABLE 2. Prevalence of medication adherence and association with selected sociodemographic characteristics among Hispanic/Latino men who have sex with men currently taking antiretroviral therapy (ART) $(N=1,673)$ - Medical Monitoring Project, United States, 2015-2019

\begin{tabular}{|c|c|c|c|c|c|c|c|}
\hline \multirow[b]{2}{*}{ Characteristic } & \multirow[b]{2}{*}{ Total no.* } & \multicolumn{2}{|c|}{ Adherence score $\geq 85^{\dagger}$} & \multicolumn{2}{|c|}{ Unadjusted } & \multicolumn{2}{|l|}{ Adjusted } \\
\hline & & No.* & $\%(95 \% \mathrm{Cl})^{\S}$ & Prevalence ratio $(95 \% \mathrm{Cl})$ & P-value & Prevalence ratio $(95 \% \mathrm{Cl})$ & P-value \\
\hline \multicolumn{8}{|l|}{ Sociodemographic variables } \\
\hline \multicolumn{8}{|l|}{ Age group (yrs) } \\
\hline $18-29$ & 192 & 126 & $65.7(57.3-74.1)$ & $0.79(0.69-0.90)$ & \multirow[t]{4}{*}{$<0.001$} & $0.85(0.76-0.96)$ & \multirow[t]{4}{*}{0.005} \\
\hline $30-39$ & 398 & 279 & $72.2(66.9-77.5)$ & $0.86(0.79-0.94)$ & & $0.88(0.80-0.96)$ & \\
\hline $40-49$ & 482 & 372 & $77.8(73.3-82.2)$ & $0.93(0.87-1.00)$ & & $0.94(0.87-1.01)$ & \\
\hline$\geq 50$ & 598 & 492 & $83.6(80.4-86.7)$ & Reference & & Reference & \\
\hline \multicolumn{8}{|l|}{ Education level } \\
\hline Less than high school & 207 & 158 & $75.2(68.3-82.2)$ & $0.95(0.86-1.05)$ & \multirow[t]{3}{*}{0.069} & - & - \\
\hline High school diploma or equivalent & 342 & 242 & $72.6(67.0-78.2)$ & $0.92(0.85-1.00)$ & & - & - \\
\hline More than high school & 1,120 & 868 & $79.1(76.3-81.8)$ & Reference & & - & - \\
\hline \multicolumn{8}{|l|}{ Household poverty level ${ }^{* * *}$} \\
\hline Above threshold & 1,024 & 801 & $79.7(76.8-82.6)$ & Reference & \multirow[t]{2}{*}{0.002} & Reference & \multirow[t]{2}{*}{0.024} \\
\hline At or below threshold & 535 & 380 & $71.5(66.8-76.2)$ & $0.90(0.83-0.96)$ & & $0.93(0.87-0.99)$ & \\
\hline \multicolumn{8}{|l|}{ Homeless $^{\dagger \dagger}$} \\
\hline Yes & 124 & 72 & $60.7(50.9-70.5)$ & $0.77(0.66-0.91)$ & \multirow[t]{2}{*}{$<0.001$} & - & - \\
\hline No & 1,546 & 1,197 & $78.5(76.0-81.0)$ & Reference & & - & - \\
\hline \multicolumn{8}{|l|}{ Risk behaviors } \\
\hline \multicolumn{8}{|l|}{ Binge drinking, previous 30 days $\S^{\S}$} \\
\hline Yes & 405 & 289 & $74.0(68.6-79.4)$ & $0.94(0.87-1.02)$ & \multirow[t]{2}{*}{0.142} & - & - \\
\hline No & 1,254 & 974 & $78.4(75.7-81.2)$ & Reference & & - & - \\
\hline Drug use, previous $12 \mathrm{mos}$ & & & & & & & \\
\hline Yes & 548 & 349 & $67.2(62.2-72.3)$ & $0.82(0.76-0.89)$ & $<0.001$ & $0.86(0.80-0.93)$ & $<0.001$ \\
\hline No & 1,114 & 916 & $81.9(79.4-84.4)$ & Reference & & Reference & \\
\hline Clinical variables & & & & & & & \\
\hline Time since HIV diagnosis (yrs) & & & & & & & \\
\hline$<5$ & 377 & 279 & $72.3(66.7-77.8)$ & $0.91(0.84-0.99)$ & 0.058 & - & - \\
\hline $5-9$ & 386 & 290 & $77.4(72.5-82.4)$ & $0.98(0.91-1.05)$ & & - & - \\
\hline$\geq 10$ & 905 & 698 & $79.2(76.3-82.1)$ & Reference & & - & - \\
\hline Symptoms of depression, previous & ks & & & & & & \\
\hline Yes & 323 & 206 & $66.3(60.3-72.4)$ & $0.83(0.76-0.91)$ & $<0.001$ & $0.91(0.83-1.00)$ & 0.026 \\
\hline No & 1,335 & 1,054 & $79.9(77.3-82.5)$ & Reference & & Reference & \\
\hline Symptoms of generalized anxiety & der, previous & $2 \mathrm{wks}^{* * * *}$ & & & & & \\
\hline Yes & 349 & 234 & $69.5(63.2-75.8)$ & $0.88(0.80-0.96)$ & 0.001 & - & - \\
\hline No & 1,315 & 1,031 & 79.4 (76.9-81.9) & Reference & & - & - \\
\hline Attended Ryan White-funded faci & r usual care & & & & & & \\
\hline Yes & 1,165 & 878 & $76.5(73.5-79.5)$ & $0.96(0.90-1.03)$ & 0.266 & - & - \\
\hline No & 436 & 341 & $79.7(75.1-84.3)$ & Reference & & - & - \\
\hline Retained in care, previous 12 mos & & & & & & & \\
\hline Yes & 1,462 & 1,122 & $78.2(75.8-80.7)$ & Reference & 0.180 & - & - \\
\hline No & 153 & 108 & $72.2(63.1-81.3)$ & $0.92(0.81-1.05)$ & & - & - \\
\hline Health insurance type & & & & & & & \\
\hline Any private insurance & 652 & 519 & $80.3(76.7-83.9)$ & Reference & 0.130 & - & - \\
\hline Public insurance only & 764 & 557 & $75.4(71.7-79.1)$ & $0.94(0.88-1.00)$ & & - & - \\
\hline $\begin{array}{l}\text { Uninsured or Ryan White HIV/AIDS } \\
\text { Program coverage only }\end{array}$ & 239 & 181 & $75.0(68.8-81.2)$ & $0.93(0.85-1.03)$ & & - & - \\
\hline Had at least one unmet need for a & ry services, $\mathrm{p}$ & evious 1 & & & & & \\
\hline At least one unmet need & 832 & 581 & $71.6(67.7-75.5)$ & $0.86(0.81-0.92)$ & $<0.001$ & $0.89(0.83-0.95)$ & 0.001 \\
\hline Received or did not need services & 836 & 687 & $83.0(80.0-85.9)$ & Reference & & Reference & \\
\hline Received adherence support servi & & & & & & & \\
\hline Yes & 624 & 474 & $77.7(73.8-81.5)$ & Reference & 0.851 & - & - \\
\hline No & 1,042 & 794 & $77.2(74.2-80.2)$ & $0.99(0.94-1.06)$ & & - & - \\
\hline
\end{tabular}

Abbreviations: $\mathrm{Cl}=$ confidence interval; $\mathrm{HIV}=$ human immunodeficiency virus.

* Numbers are unweighted.

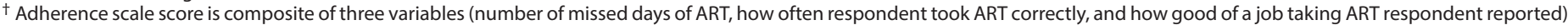
and ranges from 0 to 100 , with 100 indicating perfect adherence.

$\S$ Percentages and corresponding $\mathrm{Cls}$ are weighted percentages.

I Dash indicates that a value is not applicable.

** Poverty guidelines as defined by the U.S. Department of Health and Human Services.

${ }^{\dagger+}$ Living on the street, in a shelter, in a single-room-occupancy hotel, or in a car.

$\S \S$ Binge drinking for men is defined as five or more alcoholic drinks in one sitting

กศ Depression was assessed by using the eight-item Patient Health Questionnaire algorithm.

*** Anxiety was assessed by using the Generalized Anxiety Disorder Scale.

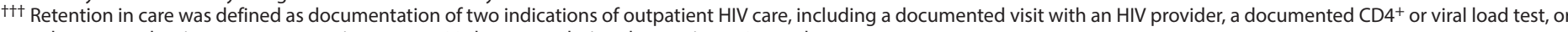
a documented resistance test or tropism assay, $\geq 90$ days apart during the previous 12 months.

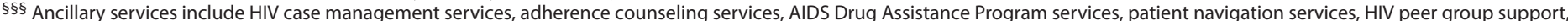

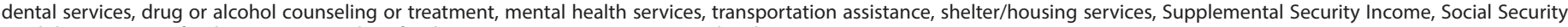
Disability Insurance, food assistance, meals or food services, interpreter services, or legal services. 
TABLE 3. Reason for most recent missed antiretroviral therapy (ART) dose* among Hispanic/Latino men who have sex with men (MSM) with diagnosed human immunodeficiency virus (HIV) infection currently taking ART and number who reported multiple reasons Medical Monitoring Project, United States, 2018-2019 ${ }^{\dagger}$

\begin{tabular}{|c|c|c|}
\hline Reason & No. ${ }^{\S}$ & $\%(95 \% \mathrm{Cl})^{9}$ \\
\hline \multicolumn{3}{|c|}{ Forgetting to take HIV medicines } \\
\hline Yes & 222 & $63.1(55.7-70.5)$ \\
\hline No & 126 & $36.9(29.5-44.3)$ \\
\hline \multicolumn{3}{|c|}{ Change in daily routine or travel } \\
\hline Yes & 156 & $42.3(36.8-47.9)$ \\
\hline No & 192 & $57.7(52.1-63.2)$ \\
\hline \multicolumn{3}{|c|}{ Fell asleep early or overslept } \\
\hline Yes & 121 & $33.6(28.7-38.5)$ \\
\hline No & 227 & $66.4(61.5-71.3)$ \\
\hline \multicolumn{3}{|c|}{ Problem getting prescription or refill for HIV medicines } \\
\hline Yes & 63 & $18.8(14.5-23.0)$ \\
\hline No & 285 & $81.2(77.0-85.5)$ \\
\hline \multicolumn{3}{|c|}{ Felt depressed or overwhelmed } \\
\hline Yes & 67 & $17.6(13.7-21.6)$ \\
\hline No & 281 & $82.4(78.4-86.3)$ \\
\hline \multicolumn{3}{|c|}{ Did not feel like taking HIV medicines } \\
\hline Yes & 41 & $13.0(8.9-17.1)$ \\
\hline No & 307 & $87.0(82.9-91.1)$ \\
\hline \multicolumn{3}{|c|}{ Drug or alcohol use } \\
\hline Yes & 41 & $11.8(7.9-15.7)$ \\
\hline No & 307 & $88.2(84.3-92.1)$ \\
\hline \multicolumn{3}{|c|}{ Side effects from HIV medicines } \\
\hline Yes & 38 & $10.7(7.4-14.0)$ \\
\hline No & 309 & $89.3(86.0-92.6)$ \\
\hline \multicolumn{3}{|c|}{ Problem paying for HIV medicines } \\
\hline Yes & 25 & $6.6(3.4-9.8)$ \\
\hline No & 323 & $93.4(90.2-96.6)$ \\
\hline \multicolumn{3}{|c|}{ In the hospital or too sick to take HIV medicines } \\
\hline Yes & 16 & $4.5(2.6-6.5)$ \\
\hline No & 332 & $95.5(93.5-97.4)$ \\
\hline \multicolumn{3}{|c|}{ Reported multiple reasons for missing ART } \\
\hline Yes & 223 & $63.9(58.1-69.7)$ \\
\hline No & 125 & $36.1(30.3-41.9)$ \\
\hline
\end{tabular}

Abbreviation: $\mathrm{Cl}=$ confidence interval.

* Respondents could select multiple reasons for missing a dose.

${ }^{\dagger}$ Data limited to 2018 cycle because of changes in skip-pattern preceding questions.

$\S$ Numbers might not sum to total because of missing data, and percentages might not sum to 100 because of rounding.

I Percentages and corresponding $\mathrm{Cl}$ s are weighted percentages.

In 2019, the U.S. Department of Health and Human Services proposed Ending the HIV Epidemic: A Plan for America (EHE) (2). Two of the four primary pillars of EHE are early HIV diagnosis and treatment of HIV infection to help persons achieve and maintain viral suppression to prevent morbidity and further transmission. CDC is working with state and local partners and other stakeholders to use interventions that support the four EHE pillars. ${ }^{\dagger \dagger}$ For example, Sin Buscar Excusas/No Excuses is a video-based intervention for Hispanic/ Latino MSM that is intended to prevent transmission by increasing sexual safety, HIV testing, and HIV care. ${ }^{\circledR \$}$ Another

\footnotetext{
$\dagger_{\dagger}$ https://www.cdc.gov/hiv/effective-interventions/a-to-z.html.

$\$ \$$ https://www.cdc.gov/hiv/effective-interventions/prevent/sin-buscar-excusas.
}

intervention, Helping Enhance Adherence to Antiretroviral Therapy (HEART), helps patients develop individualized adherence plans by using problem-solving activities to identify and address their ART adherence barriers. HEART also incorporates a patient-identified support partner to aid in meeting ART adherence goals. 99

The findings in this report are subject to at least three limitations. First, data ascertained through participant interviews, including information on ART adherence, were based on selfreport and might be subject to social desirability or recall bias. Second, results were adjusted to minimize nonresponse bias on the basis of standard methodology; however, the possibility of residual nonresponse bias remains. Finally, reasons for missing ART doses might not be exhaustive.

This report highlights barriers to ART adherence faced by Hispanic/Latino MSM with diagnosed HIV infection. Culturally tailored interventions aimed at improving adherence, particularly among Hispanic/Latino MSM who are younger, live in poverty, use drugs, and have unmet needs for ancillary services, might improve viral suppression, leading to better health outcomes and decreasing HIV transmission.

\footnotetext{
99 https://www.cdc.gov/hiv/effective-interventions/treat/heart.

Corresponding author: Stacy Crim, SCrim@cdc.gov, 404-639-2257.
}

${ }^{1}$ Division of HIV/AIDS Prevention, National Center for HIV/AIDS, Viral Hepatitis, STD, and TB Prevention, CDC.

All authors have completed and submitted the International Committee of Medical Journal Editors form for disclosure of potential conflicts of interest. No potential conflicts of interest were disclosed.

\section{References}

1. CDC. Estimated HIV incidence and prevalence in the United States, 2014-2018. HIV surveillance supplemental report, vol. 25, no. 1. Atlanta, GA: US Department of Health and Human Services, CDC; 2020. https://www.cdc.gov/hiv/library/reports/hiv-surveillance.html

2. Fauci AS, Redfield RR, Sigounas G, Weahkee MD, Giroir BP. Ending the HIV epidemic: a plan for the United States. JAMA 2019;321:844-5. https://doi.org/10.1001/jama.2019.1343

3. Carey JW, Carnes N, Schoua-Glusberg A, et al. Barriers and facilitators for antiretroviral treatment adherence among HIV-positive African American and Latino men who have sex with men. AIDS Educ Prev 2019;31:306-24. https://doi.org/10.1521/aeap.2019.31.4.306

4. Wilson IB, Fowler FJ Jr, Cosenza CA, et al. Cognitive and field testing of a new set of medication adherence self-report items for HIV care. AIDS Behav 2014;18:2349-58. https://doi.org/10.1007/s10461-013-0610-1

5. Wilson IB, Lee Y, Michaud J, Fowler FJ Jr, Rogers WH. Validation of a new three-item self-report measure for medication adherence. AIDS Behav 2016;20:2700-8. https://doi.org/10.1007/s10461-016-1406-x

6. Conviser R, Pounds MB. The role of ancillary services in client-centred systems of care. AIDS Care 2002;14(Suppl 1):S119-31. https://doi. org/10.1080/09540120220150018

7. Bieler GS, Brown GG, Williams RL, Brogan DJ. Estimating modeladjusted risks, risk differences, and risk ratios from complex survey data. Am J Epidemiol 2010;171:618-23. https://doi.org/10.1093/aje/kwp440 
8. Pappas G, Yujiang J, Seiler N, et al. Perspectives on the role of patientcentered medical homes in HIV Care. Am J Public Health 2014;104:e49-53. https://doi.org/10.2105/AJPH.2014.302022

9. Rooks-Peck CR, Wichser ME, Adegbite AH, et al. Analysis of systematic reviews of medication adherence interventions for persons with HIV, 1996-2017. AIDS Patient Care STDS 2019;33:528-37. https://doi. org/10.1089/apc.2019.0125
10. Kanters S, Park JJH, Chan K, et al. Interventions to improve adherence to antiretroviral therapy: a systematic review and network meta-analysis. Lancet HIV 2017;4:e31-40. PMID:27863996 https://doi.org/10.1016/ S2352-3018(16)30206-5 